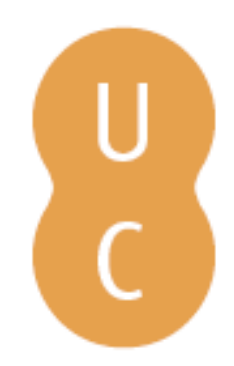

\title{
nombalina
}

\section{Sábios e poetas na construção da identidade helénica}

Autor(es): $\quad$ Várzeas, Marta Isabel de Oliveira

Publicado por: Imprensa da Universidade de Coimbra

URL

persistente:

URI:http://hdl.handle.net/10316.2/34703

DOI:

DOI:http://dx.doi.org/10.14195/978-989-721-042-6_3

Accessed : $\quad$ 26-Apr-2023 12:53:56

A navegação consulta e descarregamento dos títulos inseridos nas Bibliotecas Digitais UC Digitalis, UC Pombalina e UC Impactum, pressupõem a aceitação plena e sem reservas dos Termos e Condições de Uso destas Bibliotecas Digitais, disponíveis em https://digitalis.uc.pt/pt-pt/termos.

Conforme exposto nos referidos Termos e Condições de Uso, o descarregamento de títulos de acesso restrito requer uma licença válida de autorização devendo o utilizador aceder ao(s) documento(s) a partir de um endereço de IP da instituição detentora da supramencionada licença.

Ao utilizador é apenas permitido o descarregamento para uso pessoal, pelo que o emprego do(s) título(s) descarregado(s) para outro fim, designadamente comercial, carece de autorização do respetivo autor ou editor da obra.

Na medida em que todas as obras da UC Digitalis se encontram protegidas pelo Código do Direito de Autor e Direitos Conexos e demais legislação aplicável, toda a cópia, parcial ou total, deste documento, nos casos em que é legalmente admitida, deverá conter ou fazer-se acompanhar por este aviso.

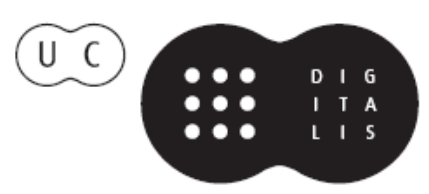




\section{Dos Homens e suas Ideias \\ Estudos sobre as Vidas de Diógenes Laércio}

Delfim Leão, Gabriele Cornelli \& Miriam C. Peixoto (coords.) 


\title{
SÁbios e PoEtas NA CONSTRUÇÃo da IDENTIDAdE HELÉNICA (Wise men and poets constructing the Hellenic identity)
}

\author{
Marta Isabel de Oliveira Várzeas \\ Universidade do Porto - Centro de Estudos Clássicos e Humanísticos
}

\begin{abstract}
Resumo: O facto de Diógenes Laércio incluir, numa obra que visa reunir as vidas e doutrinas dos filósofos ilustres, as lendas e máximas atribuídas aos Sete Sábios é indicação clara do relevante papel desempenhado por aquelas figuras na formação da identidade helénica, enquanto representantes de uma tradição sapiencial que caracterizou a mundividência arcaica e teve fundas repercussões nas épocas seguintes. A súmula de Diógenes será o ponto de partida para a reflexão sobre o modo como as máximas dos Sete Sábios foram sendo retomadas, expandidas, reformuladas e mesmo censuradas por aqueles outros sophoi ou sophistai que com eles concorreram para dar forma e expressão ao modo particular de ser Grego - os poetas, quer os cultores da poesia lírica, como Simónides ou Píndaro, quer do teatro trágico, como Sófocles.
\end{abstract}

Palavras-chave: Diógenes Laércio, Sete Sábios, Máximas, Poesia grega, Tragédia

Авstract: The fact that Diogenes Laertius included the legend of the Seven Wise Men and their maxims in a work whose aim was to collect the lives and doctrines of illustrious philosophers clearly points to the relevant part played by those Wise Men in shaping helenic identity. In fact, they represent a traditional wisdom characteristic of the archaic vision of the world with important repercussions in other periods of Greek history. Diogenes's work will serve me as a departing point for the reflexion on the ways those maxims were reformulated, expanded, and even dispraised by those other sophoi or sophistai that, like the Seven, were shaping the particular way of being a Greek-lyric poets, like Simonides or Pindar, and dramatic poets, like Sophocles.

KeY-words: Diogenes Laertius, Seven Wise Men, Maxims, Greek Poetry, Tragedy

O facto de Diógenes Laércio incluir, numa obra que visa reunir as vidas e doutrinas dos filósofos ilustres, a sua recolha de dados biográficos acerca dos Sete - e mais quatro - Sábios bem como as sentenças a eles atribuídas, parece encontrar justificação suficiente na forma como o autor percepciona o papel tutelar de algumas destas figuras relativamente àqueles que, na sua perspectiva, deram início às duas grandes tradições filosóficas gregas: a iónica e a itálica. De facto, afirma o biógrafo (1.13) que Anaximandro, o iniciador da filosofia iónica, fora discípulo de Tales, um dos do núcleo duro dos Sapientes, e Pitágoras, que iniciara a tradição itálica, tivera por mestre Ferecides de Siros e contactara também com Epiménides de Creta, dois dos nomes que Laércio acrescenta ao número tradicional dos Sete. Porém, é necessário notar que a apresentação exaustiva daquelas figuras, a quem é dedicado o Livro I, é antes de mais sintomática do reconhecimento do relevante papel por elas desempenhado na construção de uma tradição sapiencial que ajudou a dar 
forma à mundividência da pólis arcaica e que teve importantes repercussões em épocas posteriores. De resto, a sua inclusão na obra surge como uma verdadeira opção do autor, pois, apesar de não ser inédita, ao que parece ${ }^{1}$, a presença dos Sábios nos escritos sobre os filósofos antigos que serviram de fonte a Laércio, a verdade é que o próprio lembra (1.40), e implicitamente rejeita, a opinião de Dicearco, segundo a qual aqueles homens não haviam sido nem sophoi nem philosophoi mas apenas synetous e nomothetikous, "inteligentes" e "legisladores". Ora, não há dúvida de que o biógrafo, se bem que não os queira confundir com os filósofos, como bem mostra o remate deste primeiro livro ${ }^{2}$, reconhece-lhes claramente o estatuto de Sábios e, além disso, parece aceitar a visão tradicional que os associava aos poetas. Daí que, tanto a uns como a outros, como recorda de passagem na sua primeira alusão aos sophoi, tenha sido dado o nome de sophistai (1.12).

Esta referência aparentemente marginal aos poetas como sophistai, a par dos sophoi, talvez seja mais significativa do que parece à primeira vista. É que, ao estabelecer a distinção entre dois tipos de saber - o dos sábios e poetas, por um lado, e o dos filósofos, por outro - o autor convoca para o universo da sua obra essas outras figuras que desempenharam um papel absolutamente determinante na configuração do modo de ser grego e, em muitos casos, na própria reflexão filosófica, que, como sabemos, começa por se afirmar em polémico mas constante diálogo com essa tradição poética que fora, durante muito tempo, a única forma de educação na Hélade $^{3}$. Por conseguinte, podemos dizer que a evocação dos poetas está em linha de continuidade com a antiga concepção da poesia como veículo de transmissão do saber e, consequentemente, com uma visão dos seus cultores como mestres, detentores de uma sophia igualável à dos Sábios, ou, pelo menos, com idênticas repercussões ou responsabilidades na formação da identidade helénica. $\mathrm{E}$ assim se percebe por que razão, num relato dedicado às vidas e à doxografia daqueles que deram início à actividade filosófica na Grécia, abundam citações de versos, referências a poetas e até breves reflexões ou comentários sobre a arte da poesia. $\mathrm{O}$ uso da palavra sophistai para designar os poetas, aqui abonado pelas afirmações de Cratino acerca de Homero e Hesíodo (1.12), é também confirmado num passo do Protágoras de Platão (316d) em que o Abderita, em defesa da sua actividade, afirma que a sofística havia sido praticada desde sempre por homens como

\footnotetext{
${ }^{1}$ Sobre a associação entre Sábios e filósofos em outras obras acerca da história da filosofia vide Goulet 199947.

${ }^{2}$ Laércio temina o livro primeiro dizendo: "Estes são os chamados sábios. Mas deve-se falar dos filósofos."

${ }^{3}$ Xenófanes e Heraclito são dois dos primeiros exemplos dessa polémica, como o próprio Laércio testemunha nos capítulos a eles dedicados - 9.1 (= frg. 42 DK) e 9.18. Cf. frg. 11 DK de Xenófanes.
} 
Homero, Hesíodo e Simónides que a disfarçavam sob a forma de poesia. Aliás, de Simónides, como é sabido, se foi também construindo já na Antiguidade a imagem do poeta sábio, e a tradição atribuía-lhe uma extensa lista de apotegmas ${ }^{4}$. Ora, também a este nível formal, é possível encontrar um ponto de confluência entre sábios e poetas, precisamente no recurso às sentenças, as gnomai - uma forma de expressão concisa e lapidar abundantemente usada na lírica arcaica 5 .

Não será, pois, por acaso, que dos Sapientes circulasse também a informação, referida por Diógenes Laércio e que ele diz ter origem em Anaxímenes, de que teriam composto poesia, embora, à excepção de Sólon, não tenhamos conhecimento de quaisquer poemas por eles escritos e seja até provável, como defendem alguns críticos, que o não tivessem feito ${ }^{6}$.

A associação do conjunto dos Sete Sábios ao santuário de Delfos e ao deus Apolo, que aparece pela primeira vez no diálogo platónico acima citado ${ }^{7}$, e à época de Laércio já era um dado plenamente consolidado da tradição acerca daquelas figuras, é mais um dos factores de convergência com os poetas, uma vez que, como sabemos, Apolo era, juntamente com as Musas, o seu patrono - o deus da mousike $e^{8}$.

Apesar da distinção entre Sábios - associados aos Poetas - e Filósofos nota-se que, em vários momentos da obra, as linhas de demarcação entre estes grupos não só se esbatem como chegam mesmo a cruzar-se. É o que ocorre quando, a propósito de Parménides ter enveredado pela forma poética para

\footnotetext{
${ }^{4}$ Sobre Simónides e a sua tradicional inclusão no grupo dos homens sábios vide Ferreira 2005 .

${ }^{5}$ Encontram-se exemplos vários em Simónides, Píndaro ou Baquílides, entre outros. Apesar disso, o laconismo das sentenças dos Sábios não se confunde com o trabalho criativo sobre a linguagem efectuado pelos poetas arcaicos. Tem razão Gual (2007 38) ao dizer: "Pocos tratos com las versátiles musas de trenzas violetas tienen estos Sabios que, pertrechados de prudencia y sagacidad, avanzan a la conquista de la verdad com paso firme y en fila, codo a codo, como los hoplitas de sus tiempos. Esos apotegmas tan escuetos, tan desprovistos de cualquier lujo verbal, tan prosaicos, revelan bien el espíritu estricto de estos sabios (...) Reflejan bien esa mentalidad astuta, calculadora, antipoética, que exhorta a una moral basada en la prudencia y la búsqueda de beneficios materiales."

${ }^{6}$ Dúvidas sobre a suposta produção poética dos Sábios transmitida por Laércio são expressas por Goulet 1999 58-60.

${ }^{7}$ Prt. 343b. Neste passo afirma Sócrates que Tales, Pítaco, Bias, Sólon, Cleobulo, Míson e Quílon se reuniram em Delfos e a Apolo ofereceram o melhor do seu saber, gravando no templo do deus as suas máximas. Sobre as origens e desenvolvimento da lenda dos Sete Sábios na Grécia vide Busine 2002. Vide ainda Leão 2008 16-19 e Leão 2006 35-78.

${ }^{8}$ Não esqueçamos, além disso, que a equação que faz corresponder conbecimento ou sabedoria às artes das Musas ou poesia caracteriza a mundividência helénica, e tem raizes na sua mitologia. Basta lembrar os pedidos de inspiração à Musa, feitos pelos poetas épicos com base no facto de estas possuírem um conhecimento total advindo da observação directa dos acontecimentos (Il. 2.484-492); ou ainda um episódio homérico como o das Sereias (Od.12.183-190), esses seres fascinantes e perigosos cujo canto sedutor prometia um saber irresistível.
} 
o registo do seu pensamento, Diógenes afirma que o mesmo fizeram outros, dando como exemplos, não apenas os expectáveis Xenófanes e Empédocles, mas também, algo inesperadamente, Hesíodo (9.21). Ora, a referência a Hesíodo e a naturalidade com que é aproximado destes pensadores parece indicar que Diógenes Laércio reconhece aos poetas antigos - ou, pelo menos, a este uma sabedoria ou uma atitude de busca do saber equiparáveis às daqueles que primeiro filosofaram 9 .

Mas o cruzamento entre poetas, sábios e filósofos tem uma das suas expressões mais eloquentes no livro 9 (71-73), onde Diógenes refere que, segundo alguns testemunhos, que ele não identifica, Homero fora o iniciador da escola céptica, bem como os próprios Sete Sábios. E ele mesmo parece defender tal ponto de vista, ao acrescentar exemplos de Arquíloco, Eurípides e Homero que supostamente corroboram aquela opinião.

Relacionado com isto podemos ainda mencionar um dos aspectos que entra frequentemente na caracterização dos homens ilustres que constituem o objecto do seu livro, ou seja, a sua actividade como cultores de poesia, ou as suas preferências literárias. Esse é um dado valorizado por Laércio, interessado menos na doxografia do que em tudo aquilo que possa dar dos biografados uma imagem mais personalizada e próxima. E se, como no caso de um Xenófanes ou de um Heraclito, as suas opiniões a respeito das mentiras de Homero e Hesíodo importam para dar a imagem de um saber que se afirma por oposição à tradição mais antiga, nomeadamente a dos aedos, não é menos verdade que a indicação dos gostos literários de outros autores, como Tímon (9.111 sqq), Menedemo de Erétria (2.133), Pólemon (4.20) ou Arcesilau (4.31), entre muitos outros, pode ser entendida como a defesa da compatibilidade entre filosofia e poesia, que, de resto, para Diógenes Laércio, não constituiria qualquer problema.

Mas a presença da poesia na obra não se limita a este tipo de referências, antes parece mesmo estar ao serviço do próprio trabalho de composição biográfica. Com efeito, ela emerge aberta e sucessivamente nos parágrafos em que o autor transcreve poemas, quer de origem alheia - e que vêm confirmar, atestar ou completar aspectos da vida e do carácter das suas personagens quer de sua autoria e dedicados à morte dos biografados; versos, ao que tudo indica, anteriores à composição das Vidas, dado que, como o próprio afirma, se encontravam reunidos numa obra intitulada Pammetros, um vasto conjunto de poemas em metros variados. Os seus versos surgem como uma espécie de

\footnotetext{
${ }^{9}$ Neste aspecto, de alguma maneira, alinha numa visão da história da filosofia com algumas semelhanças com a de Aristóteles que, no primeiro livro da Metafísica, parece incluir Hesíodo e até Homero no conjunto dos que designa como protoi theologesantes, "os que primeiro falaram acerca dos deuses".
} 
complemento, o contributo mais pessoal do autor para a caracterização destes homens ${ }^{10}$. Mas expressam também o valor atribuído a essa outra faceta da sua actividade como escritor, e que parece ser motivo de algum orgulho. Assim, ao nível da escrita, o autor concilia dois tipos de registo - a prosa e o verso - que, na sua perspectiva, associam o talento natural (physis) e o domínio de uma técnica (techne). É, de facto, a este binómio, "natureza"/“arte”, que Laércio recorre nas considerações que expende acerca da arte da poesia e que nos dizem alguma coisa sobre o que ele pensaria de si próprio como escritor. Ao falar de um dos homónimos de Xenócrates, que havia escrito uma elegia sem qualquer qualidade poética, faz o seguinte comentário (4.15):

Isso é típico, pois os poetas quando se voltam para a escrita em prosa, têm sucesso, enquanto os prosadores, quando se abalançam à poesia, falham. Com isto se torna manifesto que a poesia é obra da natureza, a prosa é obra da técnica.

Outro momento interessante no que diz respeito ao cruzamento entre o universo da poesia e o da filosofia encontra-se em 3.56 onde a evolução da história da filosofia é comparada à evolução da tragédia:

Tal como nos primeiros tempos da tragédia o coro era o único elemento dramático, depois Téspis introduziu um actor para o coro descansar, Ésquilo um segundo e Sófocles o terceiro, contribuindo para levar a tragédia à sua forma acabada, assim também, no início, o objecto da filosofia era apenas um - a natureza - depois, numa segunda fase, Sócrates acrescentou a ética e numa terceira Platão juntou a dialéctica, levando a filosofia à perfeição.

Não é, com certeza, totalmente casual ou inconsequente este comentário. Com efeito, ele surge no livro dedicado a Platão - que, de acordo com os dados avançados no início, teria começado por compor tragédias; além disso, ocorre imediatamente antes de o autor referir a opinião de Trasilo, segundo a qual o filósofo teria organizado os seus diálogos em tetralogias por influência da tragédia. A comparação que Laércio estabelece entre o desenvolvimento do drama trágico e o da filosofia surge tão naturalmente a introduzir a questão acerca da forma pela qual Platão teria publicado os seus diálogos que parece indicar uma posição favorável à ideia da influência da tragédia sobre a obra platónica.

${ }^{10} \mathrm{O}$ que não significa que Diógenes use sempre um discurso laudatório para se referir aos seus biografados. Lembre-se o exemplo de Bíon, no livro 4, vigorosamente criticado pelo autor nos versos que lhe dedica, por, na morte, não ter sabido manter a dignidade e a coerência com os princípios que defendera em vida. 
Pesem embora os cruzamentos que acabei de referir entre o universo de uma tradição sapiencial formada por poetas e sábios e o da Filosofia, a verdade é que a distinção que o biógrafo começa por estabelecer logo no início aponta, consciente ou inconscientemente, para uma realidade que caracterizou a cultura helénica ao longo dos seus períodos arcaico e clássico: refiro-me ao clima de competição entre poetas e pensadores pelo domínio discursivo na pólis. Com efeito, a gradual emergência do discurso reflexivo, científico-filosófico e historiográfico, foi um processo consciente de emancipação relativamente ao 'cantar dos poetas', cada vez mais identificado com a mentira. Estes, porém, continuaram a afirmar a sua singularidade, e até a sua glória, e uma particular apetência para educar os cidadãos. Desta competição pelo lugar cimeiro na educação da pólis fala Platão na República, quando alude ao "antigo conflito entre poesia e filosofia" (607b), pensando talvez em Xenófanes e Heraclito, aqueles que, tanto quanto sabemos, desferiram os primeiros ataques a poetas como Homero, Hesíodo e Arquíloco, pela forma como haviam falado sobre as divindades. O próprio Diógenes, como já vimos, avança esta informação, mas não deixa de ser curioso e, mais do que isso, significativo que, no caso de Heraclito, a referência às suas violentas censuras seja apresentada como exemplo da altivez daquele pensador (9.1).

Mas, se o debate entre filosofia e poesia foi real na Grécia antiga e o seu principal motor foi o problema da verdade e o da procura da melhor forma de exprimir o divino, não menos real e importante para o desenvolvimento da cultura helénica foi a competição entre poetas e sábios pelo estatuto de educadores da Hélade.

A súmula de Diógenes Laércio fornece-nos matéria suficiente para percebermos como as máximas associadas aos Sete se constituíram como saber, tornado património comum, mas aberto à reflexão e até à polémica com os que vieram depois ${ }^{11}$. O poeta Simónides é um exemplo disso. Num dos seus poemas, que conhecemos precisamente devido à sua citação por Diógenes no livro I das Vidas (1.90), Simónides critica a ligeireza e o despropósito de um epigrama de Cleobulo de Lindos, composto para o túmulo de Midas. Eis o que diz o poeta de Céos ${ }^{12}$ :

${ }^{11}$ Apesar de ser impossível determinar a autenticidade da autoria das máximas elencadas por Diógenes - problema de que o próprio tem consciência, dada a discordância que verifica nas suas fontes (cf. 1.40-41) - bem como a exacta cronologia, parece-me aceitável que elas tenham tido origem no séc. VI e se tenham imposto como sabedoria tradicional que os poetas posteriores, sobretudo os dramaturgos, começaram a questionar e a problematizar. Busine defende justamente que, apesar de as primeiras referências escritas aos Sete Sábios se encontrarem em Heródoto e Platão, elas são apenas "le reflet d'une légende véhiculée de bouche à oreille et déformée par les aléas de la transmission orale." E afirma noutro passo: "Les préceptes delphiques, attribués dans un premier temps aux Sages, s' étendirent par la suite à la sagesse grecque, qui s'en appropria la forme tout en en variant le sens." (Busine 2002 29,38).

${ }^{12}$ Frg. 57 Bergk. A tradução aqui apresentada é de Ferreira 2005. 
Quem, confiado no seu juízo, louvaria o habitante de Lindos, Cleobulo, que aos rios eternos e às flores primaveris,

à chama do sol e da áurea lua, e aos turbilhões do mar opôs a força de uma estela?

Pois tudo é inferior aos deuses. Até a pedra

é quebrada por mãos mortais. Louco

é o homem que profere tal sentença.

Famosa era também a sua censura, dirigida a uma das máximas de Pítaco "é difícil ser bom" - a que o biógrafo também alude, mas cujo desenvolvimento conhecemos graças ao diálogo Protágoras (339b sqq), onde o poema de Simónides é abundantemente citado e discutido. Como o próprio Sócrates aí afirma (343c), a polémica evidencia a rivalidade entre o poeta de Céos e os Sábios relativamente ao estatuto de educadores que uns e outros reivindicavam. E, com efeito, de forma mais aberta ou mais camuflada, é este o sentido do diálogo que marca a relação dos poetas arcaicos e clássicos com a tradição anterior, não apenas a dos aedos - fonte de inspiração primeira - mas também a dos Sapientes. Trata-se de um diálogo verdadeiramente intertextual, para usar um termo da moderna crítica literária, através do qual as máximas destes últimos vão sendo retomadas, expandidas, reformuladas e mesmo rejeitadas por aqueles outros sophoi ou sophistai que com eles concorreram para dar forma e expressão à mundividência helénica.

Vejamos alguns dos modos de assimilação pelo universo da poesia dessa tradição sapiencial associada aos Sete. Sem pretender uma análise exaustiva, procurarei centrar-me nas máximas que suscitaram mais polémica ou que foram objecto de uma mais intensa revisitação. É que, de facto, se uma sentença como meden agan, inscrita em Delfos e atribuída a Sólon, é constantemente retomada, quer na letra quer no espírito, digamos assim, e possui um valor indiscutível e um sentido perfeitamente cristalino e unívoco, outras há cuja pregnância ou indeterminação semântica, resistem à univocidade, abrindo-se a leituras distintas, contraditórias até, de acordo com as circunstâncias históricas e ideológicas de cada autor.

É esse o caso da máxima kairon gnothi que Diógenes Laércio atribui a Pítaco de Mitilene (1.79). Por ela começarei as reflexões que seguem ${ }^{13}$. E diga-se desde já que, apesar de a tradição ligar esta sentença especificamente a Pítaco, a verdade é que outros Sapientes insistiram na importância do kairos, o que nos dá bem a dimensão universal deste valor e do consenso à sua volta. Diz Laércio (1.41) - e a mesma informação aparece no escólio ao 57-63.

${ }^{13}$ Retomo aqui, com algumas modificações, as considerações expendidas em Várzeas 2009 
v. 264 de Hipólito de Eurípides - que o sábio Quílon de Esparta afirmara: "nada em excesso; tudo o que é belo está ligado ao kairos"; e Sólon teria dito que "a palavra se sela pelo silêncio e o silêncio pelo kairos" (1.58). Por seu lado, Iâmblico (VP 49) avança a informação de que era costume atribuir-se a Pitágoras a opinião de que "a melhor coisa em qualquer acção é o kairos". E Aristóteles diz na Metafísica (1.985b; 13.1078b) que o conceito fora um dos que os Pitagóricos procuraram definir através dos números. Embora estas referências atestem o lugar central do kairos na tradição sapiencial e reflexiva gregas, tanto quanto sabemos foi Hesíodo - cuja obra Trabalhos e Dias se inscreve igualmente no âmbito da literatura sapiencial - quem primeiro afirmou a excelência deste valor, ao dizer (v. 694): "observa a medida; em todas as coisas o melhor é o kairos". Outras ressonâncias desta mesma ideia hesiódica vamos encontrá-las também na máxima mais conhecida de um outro dos Sete - o já citado Cleobulo, cujo apotegma era metron ariston (D.L. 1.93).

O conceito possuía, como mostram estes exemplos, evidentes afinidades com o de metron, a medida, mas talvez contivesse também uma nuance de precisão, significando quer o momento quer o ponto certo, o equilíbrio ${ }^{14}$. Seja como for, é clara a sua acepção moral de aplicação prática, e a sua valorização como fundamento do agir humano. E é nesse sentido que ele vai aparecer na colectânea de poemas atribuídos a Teógnis (vv. 401-402), aí também associado à máxima meden agan, agora ligeiramente modificada ${ }^{15}$ : "Por nada correr em excesso: em todas as acções humanas o melhor/ é o kairos."

Mas é porventura em Píndaro que o kairos se torna um conceito axiológico absolutamente nuclear. Juntamente com sophrosyne, "moderação", e metron, "medida", ele era um dos pilares da verdadeira sabedoria com que o aristos devia conduzir a sua vida ${ }^{16}$. Para dar apenas um exemplo, entre muitos, cito a $13^{\mathrm{a}}$ ode Olímpica (v. 48), na qual se notam os ecos muito claros da máxima de Pítaco kairon gnothi e bem assim a de Cleobulo, metron ariston: "em cada coisa assiste a medida;/ conhecer o kairos é o melhor." Como se vê, o kairos era, de facto, sentido como um princípio de regulação ética validado por uma tradição muito antiga, que remontava a Hesíodo e fora consolidada pelos Sábios e pelos poetas.

${ }^{14}$ Wilson (1980) analisa as ocorrências do vocábulo desde a sua aparição mais antiga, em Hesíodo, até Plutarco e conclui que, anteriormente ao séc. V, o seu sentido é quase exclusivamente o de "justa medida". Para um estudo mais aprofundado deste conceito e da sua evolução semântica, vide a monografia de Tredé 1992. Sobre o significado de metron na Época Arcaica, vide Prier 1976.

${ }^{15}$ Considera Wilson (1980 179) que estes versos de Teógnis são uma adaptação do v. 694 de Trabalhos e Dias de Hesíodo. Prier (1976 164 n. 9) nota que o passo do poeta beócio é a fonte da relação que os Sofistas hão-de estabelecer entre metron e kairos.

${ }^{16}$ Cf. O. 13.47-48; P. 1.81-82; P. 4.508; N. 8.4. 
Algo muda, porém, ao longo do séc. $V$, e dessa mudança dá bom testemunho a poesia trágica, que espelha a inflexão semântica que o conceito vai sofrendo, sem dúvida por influência da nova retórica dos Sofistas ${ }^{17}$. É nesta altura que se torna dominante o seu significado como "tempo oportuno" ou "ocasião oportuna"18.

Diz Diógenes Laércio (9.52) que Protágoras fora o primeiro a estabelecer a dynamis kairou, "a força da oportunidade". Não sabemos qual seria exactamente o lugar do kairos no seu pensamento, mas é provável que tivesse sobretudo uma aplicação política, porquanto o Sofista, de acordo com o que afirma no diálogo platónico homónimo, se assumia como mestre da "arte de gerir a cidade e de transformar homens em bons cidadãos” (P1. Prt. 319a). Quem pretendesse ter sucesso numa pólis democrática necessitava não apenas de saber como discursar de forma persuasiva, mas também de ter o sentido da oportunidade na apresentação das suas propostas, bem como a capacidade de discernir o melhor momento para agir.

Todavia, outros testemunhos há a indicar que o kairos pode ser um exemplo da apropriação que os Sofistas fizeram de conceitos morais que tinham enformado a mundividência helénica, e que, pela expansão da sua carga semântica tradicional, passaram a ser usados em contextos moralmente mais flexíveis. Desta flexibilidade moral é exemplo um passo do tratado conhecido como Dissoi Logoi $(2.19-20)^{19}$, escrito provavelmente no final do séc. V, onde o autor anónimo, para apoiar as suas afirmações sobre o belo e o vergonhoso, cita uns versos, de autoria desconhecida para nós, que apresentam o que dizem ser "uma nova regra para os mortais". Que diz essa regra?: "nada é completamente belo nem vergonhoso, mas é o kairos que transforma estas coisas, fazendo-as vergonhosas ou belas. Numa palavra, no kairos tudo é belo, fora dele, vergonhoso."

As palavras são suficientemente claras da nova concepção de kairos como a ocasião, o momento certo que dita a qualidade das acções. Nada existe essencialmente bom ou mau, dependendo esta avaliação apenas da adequação à circunstância, do seu kairos.

O relativismo que está por detrás deste pensamento não resolve, porém,

${ }^{17}$ Sobre a retórica sofística e as suas relações com a tragédia do séc. V, vide, entre outros, Poulakos 1995, Schiappa 1999, Halliwell 1997, Goldhill 1997, Schmalzriedt 1980 e Ober — Strauss 1990.

${ }^{18}$ A ideia de "momento oportuno" começa a surgir já em Píndaro, como parece indicar, por exemplo, P. 4.286, 508 ou N. 7.58. Sobre o sentido de kairos na tragédia vide Race 1981.

${ }_{19}$ As ideias defendidas neste tratado de autor anónimo encontrado entre as obras de Sexto Empírico, a estrutura antilógica de alguns dos seus capítulos e a referência à guerra do Peloponeso são algumas das razões que levam a que seja hoje mais ou menos consensual a ideia de que terá sido composto por um Sofista alguns anos após aquela guerra. Cf. Robinson 1979 e 2001 . 
a questão essencial: qual o critério para determinar o momento oportuno, a circunstância certa?

Um conhecido passo de Hipólito de Eurípides, de 428 a.C., vem introduzir essa nota problemática. Trata-se do momento em que Fedra, acedendo a revelar à Ama a sua paixão pelo enteado, se refere a duas espécies de aidos (vv. 385387): "uma não é má, a outra é a ruína das casas. Se o kairos fosse claro, tendo as mesmas letras, não seriam duas coisas [distintas]."

Fedra dá conta do problema inerente à absolutização do kairos como princípio orientador das escolhas morais e aponta as suas debilidades. E fá-lo através de um dado novo, que é agora chamado à colação e estava muito em voga nas discussões que, à época, se faziam acerca da linguagem: a imprecisão semântica das palavras, derivada de os onomata conterem em si mesmos a duplicidade e as contradições manifestadas nos pragmata e impossíveis de superar pelo kairos ${ }^{20}$.

Outros ecos da polémica levantada pela ambiguidade moral do conceito de kairos surgem igualmente nas últimas peças de Sófocles. Em Electra, por exemplo, ele é um dos aspectos estruturantes da caracterização das personagens, nomeadamente, de Orestes e do Pedagogo, e ajuda a perspectivar a uma nova luz a acção trágica e alguns dos conflitos que lhe dão forma ${ }^{21}$. A peça encena, como sabemos, a vingança dos filhos de Agamémnon - Orestes e Electra exigida pela morte do pai às mãos de Clitemnestra e do seu amante, Egisto ${ }^{22}$. Ora, logo na cena de abertura fica clara, para o espectador, a dimensão quase obsessiva desta vingança, para a qual Orestes foi preparado toda a sua vida. Quando entram em cena, as personagens estão já determinadas a agir, dado que, como afirmam, aquele é o momento exacto, o kairos por que tanto esperaram e que têm de aproveitar sem demora. Não há lugar, da parte de qualquer delas, para a reflexão acerca da justiça do matricídio ou acerca dos danos colaterais que o plano doloso que engendraram poderão ter sobre Electra. Sob o influxo

${ }^{20} \mathrm{Na}$ sua edição da peça Barrett rejeita a tradução de kairos por "dividing line" proposta por Wilamowitz e traduz de acordo com o que diz ser o sentido geral da palavra no séc. V, o de "appropriate". A rejeição da proposta do famoso helenista justifica-a Barrett por não encontrar qualquer prova de que esse sentido fosse concebido pelos Gregos, dado que, em sua opinião, kairos é normalmente o certo por oposição ao errado e não a distinção entre ambos. Parece-me, no entanto, que dos usos do vocábulo, e desta fala de Fedra em particular, não está ausente a ideia de que ele sirva para estabelecer a fronteira entre o bem e o mal, aqui entre a boa e a má aidos. Quanto à tradicional ambivalência de aidos, Barrett aponta um passo de Hesíodo (Erga 317319) como sua primeira ocorrência, mas, na verdade, é em Homero que ela surge pela primeira vez, em Ilíada 24.44-45. Sobre o conceito de aidos e a sua presença na Literatura grega, vide a monografia de Cairns 1993.

${ }^{21}$ Um excelente estudo desta peça encontra-se na edição comentada de Kells 1973. O significado dramático de outros conflitos presentes na peça, como o expresso pela antinomia dolos/dike, é explorado por Macleod 2001. Cf. ainda Várzeas 2009 171-236.

${ }^{22}$ O tema da vingança na tragédia grega foi objecto da análise de Burnett 1998. 
educativo do Pedagogo, Orestes já interiorizou e decidiu há muito tempo que tem de matar a mãe e, por isso, não mostra sinais de dúvida ou hesitação; e depois do acto consumado, já no final da peça, não há também espaço para o remorso ou o arrependimento, ao contrário do que acontece nas tragédias de Ésquilo e Eurípides que trataram o mesmo mito. Tudo se passa num mundo sufocado pelo ódio ${ }^{23}$, um mundo do qual os deuses se ausentaram, e no qual, para os homens, como diz Orestes, o kairos é o maior guia de todas as acções (v. 76).

Passemos agora a uma outra sentença, também atribuída por Diógenes Laércio (1.77) a Pítaco, e que me parece ter inspirado, pelo menos em parte, a construção da personagem de Creonte na Antígona de Sófocles ${ }^{24}$. Trata-se da sentença arche andra deiknysin - "o poder mostra o homem".

No primeiro discurso que profere em cena, Creonte anuncia o seu programa de governo para a cidade de Tebas e nele afirma o novo governante o seu compromisso exclusivo com a lei e com o bem da cidade, compromisso que se traduzirá na justiça e imparcialidade das suas medidas, em sacrifício, se preciso for, de familiares e amigos. Mas o ponto de partida para estas afirmações é a seguinte declaração (vv. 175-177): "É impossível conhecer bem a alma de um homem, a sua maneira de pensar e a sua determinação antes de ele se exercitar no poder e nas leis."

A máxima de Pítaco, aqui expandida por Creonte,é apenas uma das marcas do carácter sentencioso e moralizante do seu discurso, construído segundo o padrão de uma 'retórica do poder', que Sófocles vai repetindo nas figuras de chefes prepotentes, como Menelau e Agamémnon da peça Ájax. O seu modus loquendi possui todos os tiques de uma afirmação de autoridade, patenteada no recurso a máximas e afirmações generalizantes que criam uma ilusão de verdade absoluta e visam impedir o contraditório ${ }^{25}$. Não seria também esse modo típico de enunciação que Sófocles visava, ao desenhar Creonte com estes traços?

Como é habitual, o dramaturgo coloca na boca da sua personagem afirmações que se voltarão contra ela, pois, se não pode haver palavras mais certeiras do que estas sobre o efeito revelador do exercício do poder sobre o carácter do homem, no caso presente essa revelação far-se-á no sentido contrário ao pretendido. Creonte pensa vir a mostrar-se um homem de carácter irrepreensível, quando, afinal, se mostrará de uma inflexibilidade e intransigência que ofenderão os próprios deuses e, por isso, o seu fim será a

\footnotetext{
${ }^{23}$ Daí, na expressão de Fialho (1992 57), a “angústia de horizontes" em que a peça deixa o espectador.

${ }^{24}$ Para uma compreensão global dos principais problemas levantados nesta peça e dos conflitos entre as várias personagens, vide Griffith 1999.

${ }^{25}$ Uma análise da retórica de Creonte pode encontrar-se em Várzeas 2009 85-95.
} 
desgraça. Em termos dramáticos, os ecos da sentença de Pítaco funcionam também como um convite dirigido ao espectador para que assista à revelação desta personagem, que vai ser posta à prova ao longo do drama, e para que confirme a veracidade daquela máxima.

Mas há outros aspectos do pensamento deste Sábio que o espectador é chamado a reconsiderar, nomeadamente a questão, determinante nesta peça, da lei e dos seus fundamentos. Com efeito, a referenciação absoluta às leis da cidade que caracteriza o discurso e a actuação de Creonte na tragédia, parece-me poder ligar-se a uma outra informação que Diógenes Laércio nos dá acerca de Pítaco, ele que exercera o poder em Mitilene durante alguns anos. Diz Laércio (1.77) que, à pergunta sobre qual a melhor forma de autoridade, o Sábio terá respondido "a das tabuínhas ornamentadas, querendo dizer, a lei".

Ora, se aparentemente a defesa das leis da cidade, assumida por Creonte, é uma atitude justa e expectável num bom governante, ela manifesta-se totalmente errada e, mais do que isso, ímpia, quando entra em conflito aberto com as 'leis não escritas', de emanação divina, defendidas por Antígona, e quando, contrariamente aos princípios democráticos da Atenas em que a tragédia foi apresentada, Creonte se recusa a ouvir os cidadãos, achando que o Estado pertence a quem manda.

De uma maneira geral, as opiniões dos Sábios apresentam-se como uma forma alternativa de ver o mundo relativamente à axiologia homérica - que servia de modelo educativo para os nobres - e aos seus ideais de arete e time. Aqueles são portadores de uma visão mais realista da vida humana, uma visão anti-heróica e mais conforme às circunstâncias sociais, económicas e políticas da pólis arcaica e aos tempos de insegurança e de profundas transformações que caracterizam essa época e de que a Odisseia contém já alguns sinais ${ }^{26}$. Neste mundo em mudança há que procurar auto-preservar-se e precaver-se contra a inconstância e a maldade da maioria dos homens, como diz o Sábio Bias, cujo apotegma era, segundo Diógenes Laércio (1.88) - oi pleistoi kakoi. Em geral, os Sapientes defendem uma ética pragmática, um comportamento orientado pela ideia de que tudo muda entre os homens, não sendo sensato nem prudente ter como seguras as relações de amizade ou de inimizade. Tal pragmatismo está em completa contra-corrente com os valores defendidos pelos guerreiros homéricos, os seus ideais de excelência e de honra, e a distinção absolutamente clara para eles entre a solidariedade devida aos philoi e o ódio devido aos echthroi.

É justamente esta oposição entre o mundo heróico de antanho e uma nova realidade social, mais ou menos refractária ao heroísmo como projecto de

\footnotetext{
${ }^{26}$ Sobre as circunstâncias históricas em que terão vivido os Sapientes, bem como sobre a sua particular forma de sabedoria, vide Gual 2007 13- 47.
} 
vida, que dá corpo ao conflito central da tragédia Ajax de Sófocles ${ }^{27}$, peça que fala da síntese impossível entre dois modelos existenciais irreconciliáveis - o de Ájax, o guerreiro educado de acordo com os antigos ideais heróicos, fechado num universo de fronteiras bem definidas, inflexível e incapaz de se subordinar a uma nova ordem que o faria ceder, render-se, mudar o carácter; e o de Ulisses, o homem novo, aberto à mudança, mas também mais permeável a uma certa fragilidade moral, embora a peça não explore esse lado da personagem.

Ironicamente, porém, é da boca do próprio Ájax que ouvimos os ecos das afirmações de Bias sobre a forma como se devem gerir as relações entre os homens. Segundo Diógenes Laércio (1.87), dizia o famoso Sábio que se devia cultivar a amizade como quem um dia há-de passar ao ódio, porque a maioria dos homens são maus. Notem-se as reflexões de Ájax (vv. 678-683) 28 :

Sei desde há pouco tempo que um inimigo só deve odiar-se na medida em que poderá de novo ser nosso amigo, e, quanto a quem é amigo, quero servi-lo e ajudá-lo, pensando que ele não se manterá assim para sempre. É que, para a maioria dos mortais, o porto de abrigo da camaradagem não é de confiança.

"Sei desde há pouco tempo", diz Ájax, mas isso não implica a real aceitação de tais princípios. A acção subsequente mostrará que a aprendizagem não chegou a realizar-se verdadeiramente. Não há lugar para o herói neste mundo de novas regras, no qual já não importam a arete, a excelência individual, nem o seu reconhecimento social pela time, isto é, a honra. Ájax não possui um carácter maleável que lhe permita adaptar-se, suportar a humilhação, prescindir da sua honra, enfim, relativizar - o que implicaria tornar-se irreconhecível, anular-se como o homem que aprendeu a ser. É uma figura de excepção, um herói cujos valores não encontram eco naqueles que o rodeiam, nem sequer entre os que o amam. Por isso é impermeável à persuasão dos amigos e só encontra uma saída - o suicídio.

A tragédia sofocliana, como bem mostra o exemplo de Ájax, constrói personagens excepcionais, cuja radicalidade de carácter lhes confere uma dimensão quase demónica, no sentido em que Heraclito dizia que o ethos é um daimon para o homem (frg. 119 DK). Mas é a partir desses seres extraordinários, complexos, que a tragédia procura tocar o cerne da condição humana. Por isso o homem trágico de Sófocles está sempre muito para além desse pragmatismo existencial, algo simplista, de quem apenas deseja viver o melhor possível. Ájax

${ }^{27}$ De facto, o princípio ético, verdadeiramente central no pensamento grego antigo, segundo o qual se deve fazer bem aos amigos e mal aos inimigos, é objecto de profunda reflexão e questionamento na tragédia sofocliana, como muito bem mostrou Blundell 1989. Cf. a sua análise de Ajax, pp. 60-105.

${ }^{28}$ A tradução é de Rocha Pereira 2003. 
é um dos exemplos mais elucidativos da afirmação dessa complexidade do humano.

Um último exemplo de Sófocles permite-nos perceber como a tragédia pega nestas máximas da sabedoria tradicional e as vira do avesso, por assim dizer, para mostrar como princípios de uma moralidade aparentemente irrepreensível podem sempre ser desvirtuados e conduzir a fins inesperados e a situações de conflito insanável. Refiro-me a Filoctetes, de 409, onde uma outra máxima que Laércio (1.88) atribui ao mesmo Bias - peisas labe, me biasamenos: "toma pela persuasão, não pela força" - é completamente subvertida e pervertida por esse novo Ulisses que, nesta peça, é desenhado com traços muito negativos de carácter: é o homem sem escrúpulos, interesseiro, mentiroso, personagem criada à imagem dos políticos demagogos, formados nas artes da palavra e que, neste fim de século, iam conduzindo Atenas para um caminho de ruína que haveria de se mostrar irreversível ${ }^{29}$.

Também ele defende o abandono do uso da força em favor do da persuasão $^{30}$ e nesse sentido ensina e industria o ingénuo filho de Aquiles, Neoptólemo, a quem, a princípio, a ideia de enganar Filoctetes causa grande indignação, dizendo preferir levá-lo pela força. Falam por si a palavras de Ulisses (vv. 96-99):

Filho de um ilustre pai, também eu, quando novo, tinha a língua preguiçosa e a mão pronta;

mas agora, com provas firmadas, vejo que para os mortais é a língua, não as acções, que tudo conduz.

Neoptólemo acaba por ceder, levado pelos efeitos da linguagem enganadora do Cefalénio, e ele mesmo, através da persuasão, acabará por iludir o inocente Filoctetes, inflingindo-lhe um duro golpe de que este só recuperará plenamente no final da peça, por intervenção directa de Héracles ex machina.

A persuasão, defendida por Ulisses,é, afinal, puro engodo, mentira,e, por isso, exerce sobre Filoctetes um efeito tão ou mais devastador do que o da força. Os dois pólos do que deveria ser uma antítese - peitho e bia - passam a identificar-se plenamente, sendo a persuasão, ela mesma, uma forma de violência.

Outros exemplos se poderiam apresentar, mas parece-me que os até aqui analisados mostram bem como as máximas da tradição sapiencial associada

\footnotetext{
${ }^{29}$ Para uma análise da actuação da personagem de Ulisses aos longo da peça, vide Blundell 1987 e Ferreira 1990 51-74.

${ }^{30} \mathrm{O}$ tema da persuasão, do poder da palavra e o da comunicação são alguns dos mais importantes filões explorados nesta peça que reflecte as discussões contemporâneas acerca da linguagem e o ambiente de autêntica logocracia que caracterizava a Atenas finissecular. Cf. Podlecki 1966; Taplin 1971; Rose 1976; Goldhill 1997; Várzeas 2009 237-282.
} 
aos Sete e de que Diógenes Laércio nos oferece uma lista bastante exaustiva, foram sendo reformuladas pelos poetas e estiveram por vezes no centro de uma profunda reflexão sobre a vida humana que tanto a Lírica arcaica, quanto principalmente a tragédia do séc. $V$ desenvolveram. E assim, dada a importância cultural e espiritual que a lenda dos Sete Sábios teve na formação da identidade helénica, é natural a atenção que Laércio lhes dedica, atribuindo-lhes o papel de precursores nesse longo caminho em que a Filosofia surgirá como principal guia, mas que também os poetas ajudaram a desbravar. 


\section{Bibliografia}

W. S. Barrett (1992), Euripides. Hippolytos. Oxford, Clarendon Press. [1 $1^{\mathrm{a}} \mathrm{ed}$. 1964]

M. W. Blundell (1989), Helping Friends and Harming Enemies. A Study in Sophocles and Greek Ethics. Cambridge/New York, Cambridge University Press.

M. W. Blundell (1987), "The Moral Character of Odysseus in Philoctetes", GRBS 28 307-329.

A. P. Burnett (1998), Revenge in Attic and Later Tragedy. Berkeley, University of California Press.

A. Busine (2002), Les Sept Sages de la Grèce antique. Transmission et utilisation d'un patrimoine légendaire, d' Hérodote à Plutarque. Paris, De Boccard.

D. Cairns (1993), Aidos. Psychology and Ethics of Honour and Shame in Ancient Greek Literature. Oxford, Clarendon Press.

J. R. Ferreira (1989), O Drama de Filoctetes. Coimbra, INIC.

L. N. Ferreira (2005), Mobilidade poética na Grécia Antiga: uma leitura da obra de Simónides. Coimbra. [dissert. polic.]

M. C. Fialho (1992), Luz e Trevas no Teatro de Sófocles. Coimbra, CECH/ INIC.

M. Gigante (1984), “Diogene Laerzio: da poeta a prosatore”, Sileno 10245248.

S.D.Goldhill(1997), “The Language of Tragedy: Rhetoric and Communication” in P. E. Easterling, ed. The Cambridge Companion to Greek Tragedy. Cambridge, University Press 127-150.

R. Goulet (1999), "Livre I: Introduction, traduction et notes" in M.-O. Goulet-Cazé, ed. Diogène Laerce: Vies et Doctrines des Philosophes Illustres. Paris, Librairie Générale Française 45-64.

M.-O. Goulet-Cazé, ed. (1999), Diogène Laerce: Vies et Doctrines des Philosophes Illustres. Paris, Librairie Générale Française.

M. Griffith (1999), Sophocles. Antigone. Cambridge, University Press.

C. G. Gual (2007), Los Siete Sabios (y tres mas). Madrid, Alianza Editorial.

S. Halliwell (1997), "Between Public and Private: Tragedy and Athenian Experience of Rhetoric" in C.Pelling, ed. Greek Tragedy and the Historian. Oxford, Clarendon Press 121-141. 
J. H. Kells (1973), Sophocles. Electra. Cambridge, University Press.

D. Leão (2006), "A tradição dos Sete Sábios: o sapiens enquanto paradigma de uma identidade" in D. F. Leão - J. R. Ferreira - M. C. Fialho, Paideia e cidadania na Grécia antiga. Coimbra, Ariadne 35-78.

(2008), Plutarco. O Banquete dos Sete Sábios. Trad., intr. e notas. Coimbra, Classica Digitalia/CECH.

H. S. Long (1964), Diogenis Laertii Vitae Philosophorum recognovit brevique adnotatione critica instruxit H. S. Long. Oxford, Clarendon Press.

L. Macleod (2001), Dolos \& Dike in Sophocles' Electra. Leiden, Brill.

J. Ober - B. Strauss (1990), "Drama, Political Rhetoric and the Discourse of Athenian Democracy" in J. J. Winkler - F. I. Zeitlin, eds. Nothing to do with Dionysos? Athenian Drama in its Social Context. Princeton, University Press 237-270.

A.J. Podlecki (1966), "The Power of the Word in Sophocles' Philoctetes", GRBS 7 233-245.

J. Poulakos (1995), Sophistical Rhetoric in Classical Greece. Columbia, University of South Carolina Press.

R. A. Prier (1976), "Some Thoughts on the Arcaic Use of Metron", $C W 70$ 161-169.

W. H. Race (1981), “The Word kairós in Greek Drama”, TAPhA 111 197213.

T. Robinson (1979), Contrasting Arguments. An Edition of the Dissoi Logoi. New York, Arno Press.

(2001), "The Dissoi Logoi and Early Greek Skepticism" in A. Preus, ed. Essays in Ancient Greek Philosophy: Before Plato. Albany, SUNY Press 187-198.

M. H. Rocha Pereira et al. (2003), Sófocles. Tragédias. Coimbra, Minerva.

P. W. Rose (1976), "Sophocles' Philoctetes and the Teachings of the Sophists", HSPh 80 49-105.

E. Schiappa (1999), The Beginnings of Rhetorical Theory in Classical Greece. New Haven, Yale University Press.

E. Schmalzriedt (1980), "Sophokles und die Rhetorik", Rhetorik 1 89-110.

O. Taplin (1971), "Significant Actions in Sophocles' Philoctetes", GRBS 12 25-44.

M. Trédé (1992), Kairos, l'à-propos et l'ocasion: le mot et la notion, d' Homère à la fin du IVe siècle avant J.-C. Paris, Klincksieck. 
M. Várzeas (2009), A força da palavra no teatro de Sófocles. Entre retórica e poética. Coimbra, FCT-FCG.

J. R.Wilson (1980), “Kairos as ‘due measure”, Glotta 58 177-204. 